Agro-Science Journal of Tropical Agriculture, Food, Environment and Extension Volume 10 Number 3 September 2011 pp 55 - 59

ISSN 1119-7455

\title{
EFFECT OF SELECTION ON AMYLOSE AND AMYLOPECTIN CONCENTRATION IN MAIZE (ZEA MAYS L.)
}

\author{
Onyishi ${ }^{1}$ G. C . and $\mathrm{Obi}^{2}$, I. U \\ ${ }^{1}$ Department of Crop Science and Technology, Federal University of Technology, Owerri, \\ Nigeria. \\ ${ }^{2}$ Department of Crop Science, University of Nigeria, Nsukka, Nigeria.
}

\begin{abstract}
Two cycles of reciprocal recurrent selection at the University of Nigeria, Nsukka shifted the average percentage amylopectin of the eight populations of maize (Zea mays L.) from 74.50 to 81.30 per cent, 74.00 to 82.00 percent, 77.50 to 82.50 percent, 76.00 to 82.00 percent, 77.00 to 82.5 per cent, 74.50 to 82.05 per cent, 75.50 to 82.30 per cent and from 77.00 to 82.32 percent. Selection was not effective in developing high amylose strain. The average percentage amylose of the eight populations of maize decreased from 25.50 to 20.00 percent, 26.00 to 19.30 percent,22.50 to 20.00 percent, 24.00 to 20.10 percent, 23.00 to 19.31 percent, 25.50 to 19.40 percent, 24.50 to 20.41 percent, and 23.00 to 19.23 percent. The developed synthetics can be used as commercial varieties per se, as reservoirs of germplasm for further improvement, and for the extraction of superior inbred lines for use in hybrid maize production.
\end{abstract}

Key words: Reciprocal Recurrent Selection, Amylopectin, Amylose, Maize synthetics, Germplasm

\section{INTRODUCTION}

Nutritionally, maize grain is primarily carbohydrate but contains small proportions of protein, oil and some minerals. Normal maize carbohydrate consists of about $20.0-30.0$ per cent amylose and $70-80$ per cent amylopectin. These components vary with variety of seed and environmental conditions (Jugenheimer, 1976). Waxy starch or amylopectin of maize has different commercial uses. It can be used as a substitute of cassava starch in the manufacture of pudding and adhesives, raw material for industrial manufacturing of glucose, gum, dextrin, syrup and alcohol(Anon, 2011; Smith, 1974). There is potential industrial outlet for a new type of maize with starch of high amylose content (Zuber et al., 1958). Studies have shown that amylose, like other long unbranched molecules can be used to form thin, transparent films similar to cellophane and also fibers (Zuber et al., 1958). Bear (1958) found a simple recessive gene, designated ae-gene (the amylose extender gene) that changed the amyloseamylopectin ratio from $1: 3$ to $1: 1$ in mature maize endosperm without reducing the total starch production. The ae-gene can be used to produce starch with 55-77 per cent amylose (Creech and Alexander 1978), and provided the basis for the development of amylo-maize. Modifier genes in the presence of ae-gene may further alter the percentage amylose along a nearly continuous scale. Betty (2011) reported that

genetic variants of field corn include waxy maize, which produces a starch with 98 to 100 percent amylopectin, and high-amylose starches, which have amylose contents of 55\%, 70\% and higher. High-amylose starches retrograde more extensively than normal starches and are less digestible.

Comstock, Robinson and Harvey (1949) proposed reciprocal recurrent selection as one of the most important breeding methods for developing improved commercial varieties. It is designed to increase the frequency of desirable alleles for quantitative traits in breeding population as well as the maintenance of genetic variability for further improvement. Breading for improved amylose and amylopectin is not only possible but achievable judging from various reports such as that of Betty (2011); Onyishi and Obi (1991) who reported an encouraging progress in breeding for improved amylose and amylopectin; and Obi and Onyishi (1994) who reported significant improvement in protein content of maize from two cycle of reciprocal recurrent selection and observed that dominant gene action is very important in breading for chemical constituents.

The objectives were to develop maize synthetics of 50.0 per cent and above amylose, 
80.0 per cent and above amylopectin and to develop reservoirs of germplasm for further improvement.

\section{MATERIALS AND METHODS}

The materials used in the study involved four open-pollinated early maturing varieties,DMR-ESR-Y,EV-8431-SR-BC 4 ,DMRESR-W,IK(1)-8149-SR-BC ${ }_{2}$ designated as $\mathrm{A}^{1}$, $\mathrm{A}^{2}, \mathrm{~A}^{3}, \mathrm{~A}^{4}$, respectively and open-pollinated late maturing varieties, DMR-LSR-Y, West-Yellow$\mathrm{M}_{2}$, TZB-SR, DMR-LSR-W designated as $\mathrm{B}^{1}$, $\mathrm{B}^{2}, \mathrm{~B}^{3}, \mathrm{~B}^{4}$, obtained from the International Institute for Tropical Agriculture (IITA) Ibadan, Nigeria. Two cycles of reciprocal recurrent selection were completed in the populations at the University of Nigeria research farm, Nsukka $\left(6^{0} 51^{\prime} \mathrm{N} 7^{0} 29 \mathrm{E}\right.$ altitude $\left.400 \mathrm{~m}\right)$. The procedure outlined by Comstock, Robinson and Harvey (1949) was followed with minor departure. The design for the field evaluation trial was randomized complete block design (RCBD) with three replications. The spacing was $0.25 \mathrm{~m}$ within and $0.75 \mathrm{~m}$ between rows at one plant per hill, giving a theoretical plant population of 53,333 per hectare. Harvesting was done when the plants had reached physiological maturity using black layer formation as an index of maturity (Baker, 1973)

The method of Hassid and McGready (1943) was used to determine amylose content and the amylopectin content was obtained by difference. Data on number of days to 50 percent silking were also obtained.

Data were analysed according to Steel and Torrie (1980). Fisher's Least Significant difference (F-LSD) was used to compare differences between means after the preliminary F-test (Carmer and Swanson, 1971; Obi 2002). A t-test was used to compare differences between the original and derived populations.

\section{RESULTS AND DISCUSSION}

The percentage amylose in the first and second cycles is shown in Table 1 . There were significant reductions in all the populations except in population $\mathrm{B}^{3}$ that decreased but not significantly (Table 2 ). In respect to amylopectin content, there were significant increases in all the eight populations (Tables 3 and 4). The response for increased amylopectin can be interpreted as indicating that during recombination of the elite lines, the frequencies of desirable alleles increased with change in the proportions of different genotypes in the selection populations. The gradual increase in amylopectin content led to speculation on the type of gene action that has been most important in conditioning heterosis. If favourable dominant genes are most important, synthetics should perform progressively more in each cycle than the original populations. On the other hand, if over dominance is most important, the synthetics, especially of later cycles, should perform less, and certainly no more than the original populations (Douglas et al 1961). At this point in the programme the data support the favourable dominant genes hypothesis.

Lack of response to selection for high amylose could be attributed to the increase in amylpectin content. Cameroon (1947), Kramer and Whistler (1949), Zuber et al. (1960) reported that why the percentage of amylose increased, the percentage of amylopectin decreased and vice versa. The change, they observed, was followed by changes in the amount of starch, oil and protein produced. When the amylose proportion of starch decreased, there was a corresponding decrease in endosperm weight and increase in pericarp and germ weight resulting in concurrent increase in oil and protein. Geneticists believe that waxy maize has a defect in metabolism precluding the synthesis of amylose in the endosperm and is coded by a single recessive gene(wx) located on the short arm of chromosome 9 (Neuffer, et al. 1997; Wessler and Varagona, 1985).The result was however, in contrast with the report by Vineyard and Bear (1952), Deatherage et al. (1954), Bear (1958). They stated that the amylose extender gene can change the amylose-amylopectin ratio from 1:3 to $1: 1$ in mature maize endosperm without reducing the total starch production.

There were high percentage amylopectin of the synthetics in all the populations (Table 4) while the amylose was between low and medium. The constituents were classified based on Obi and Ihedigbo (1987) as summarized in Table 5. Each of the early and late maturing varieties maintained the maturity period, suggesting there is no relationship between amylose, amylopectin and time of maturity. Varieties that silked in less than 60 days from the date of planting were regarded as early maturing, while those that silked at 60 days and above were regarded as late maturing (Fajemisin, 1985) 
Table 1. Percentage amylose and days to 50 percent silking of eight maize populations under reciprocal recurrent selection.

\begin{tabular}{|c|c|c|c|c|c|c|}
\hline \multirow[t]{2}{*}{ Source population } & \multicolumn{3}{|c|}{ Amylose (\%) } & \multicolumn{3}{|c|}{$50 \%$ silking (days) } \\
\hline & $\mathrm{CO}$ & C1 & $\mathrm{C2}$ & $\mathrm{CO}$ & C1 & $\mathrm{C2}$ \\
\hline DMR - ESR - Y $\left(\mathbf{A}^{\mathbf{1}}\right)$ & 25.50 & 22.00 & 20.00 & 59 & 60 & 60 \\
\hline $\mathrm{EV}-8431-\mathrm{SR}-\mathrm{BC}_{4}\left(\mathrm{~A}^{2}\right)$ & 26.00 & 22.53 & 19.30 & 53 & 53 & 55 \\
\hline DMR - ESR - W $\left(\mathbf{A}^{3}\right)$ & 22.50 & 21.78 & 20.00 & 58 & 58 & 57 \\
\hline $\begin{array}{l}\text { IK }(1)-8149-S R-\left(B C_{2}\right) \\
\left(A^{4}\right)\end{array}$ & 24.00 & 21.47 & 20.10 & 60 & 62 & 59 \\
\hline DMR - LSR - Y $\left(\mathbf{B}^{\mathbf{1}}\right)$ & 23.00 & 22.57 & 19.31 & 61 & 63 & 67 \\
\hline West - Yellow $-\mathbf{M}_{2}\left(\mathbf{B}^{2}\right)$ & 25.50 & 22.73 & 19.40 & 65 & 67 & 68 \\
\hline $\mathbf{T Z B}-\operatorname{SR}\left(\mathbf{B}^{3}\right)$ & 24.50 & 21.00 & 20.41 & 64 & 62 & 66 \\
\hline DMR - LSR - W $\left(B^{4}\right)$ & 23.00 & 22.00 & 19.23 & 61 & 61 & 66 \\
\hline
\end{tabular}

Co = Original Population

Table 2: T-test table of comparison between the first and second cycle populations of high amylose

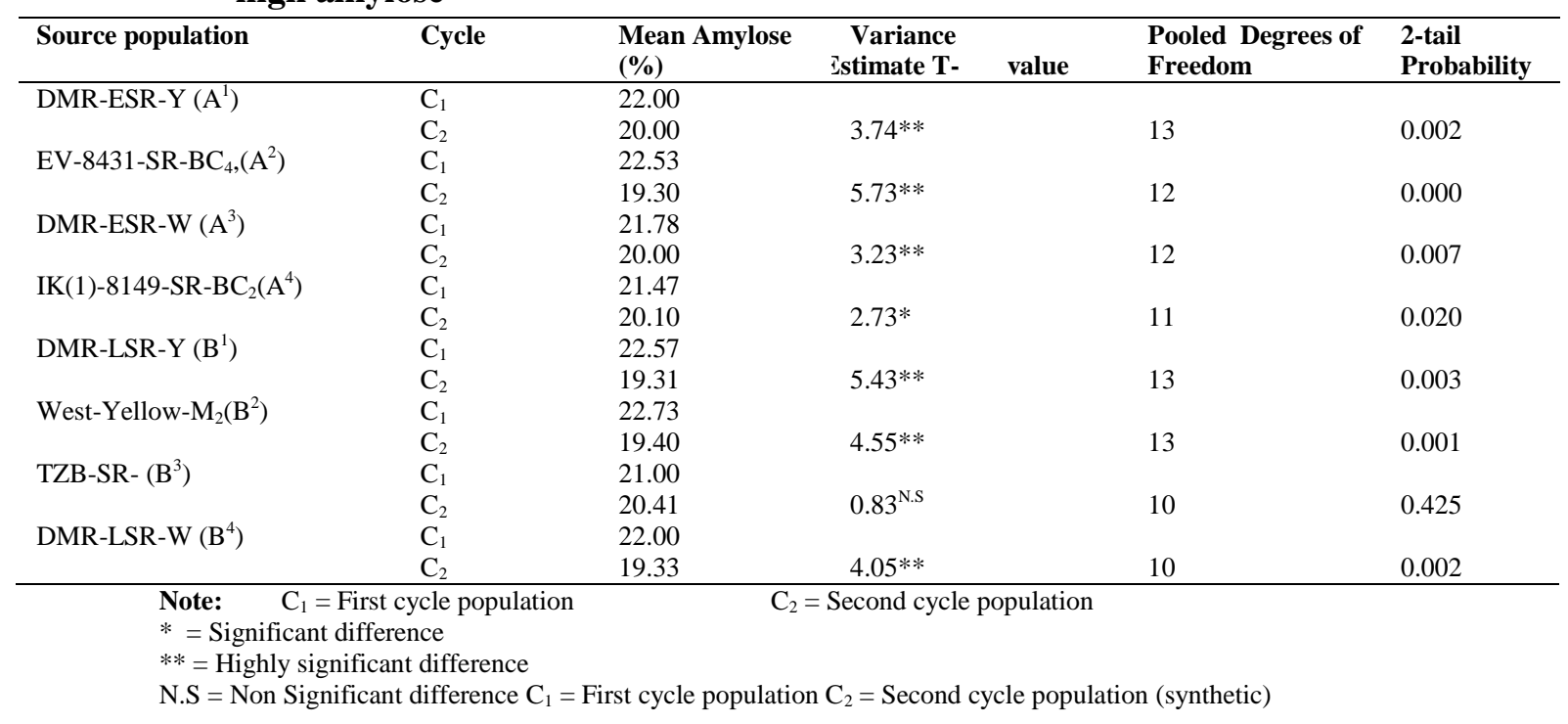

Table 3: Percentage amylopectin and days to 50 percent silking of eight maize populations under reciprocal recurrent selection

\begin{tabular}{|c|c|c|c|c|c|c|}
\hline \multirow[t]{2}{*}{ Source population } & \multicolumn{2}{|c|}{ Amylose (\%) } & \multicolumn{3}{|c|}{$50 \%$ silkig (days) } & \multirow[b]{2}{*}{$\mathrm{C} 2$} \\
\hline & $\mathrm{CO}$ & $\mathrm{C} 1$ & $\mathrm{C} 2$ & $\mathrm{C} 0$ & $\mathrm{C} 1$ & \\
\hline $\mathrm{DMR}-\mathrm{ESR}-\mathrm{Y}\left(\mathrm{A}^{1}\right)$ & 74.50 & 78.20 & 81.30 & 59 & 60 & 59 \\
\hline $\mathrm{EV}-8431-\mathrm{SR}-\mathrm{BC}_{4}\left(\mathrm{~A}^{2}\right)$ & 74.00 & 78.10 & 82.00 & 53 & 53 & 54 \\
\hline $\mathrm{DMR}-\mathrm{ESR}-\mathrm{W}\left(\mathrm{A}^{3}\right)$ & 77.50 & 78.75 & 82.50 & 58 & 58 & 56 \\
\hline $\mathrm{IK}(1)-8149-\mathrm{SR}-\left(\mathrm{BC}_{2}\right)\left(\mathrm{A}^{4}\right)$ & 76.00 & 79.40 & 82.00 & 60 & 62 & 60 \\
\hline $\mathrm{DMR}-\mathrm{LSR}-\mathrm{Y}\left(\mathrm{B}^{1}\right)$ & 77.00 & 77.80 & 82.55 & 61 & 63 & 68 \\
\hline West - Yellow $-\mathrm{M}_{2}\left(\mathrm{~B}^{2}\right)$ & 74.50 & 77.50 & 82.04 & 65 & 67 & 66 \\
\hline $\mathrm{TZB}-\mathrm{SR}\left(\mathrm{B}^{3}\right)$ & 75.50 & 80.00 & 82.30 & 64 & 62 & 67 \\
\hline $\mathrm{DMR}-\mathrm{LSR}-\mathrm{W}\left(\mathrm{B}^{4}\right)$ & 74.00 & 79.10 & 82.32 & 61 & 61 & 64 \\
\hline
\end{tabular}

$\mathrm{C}_{0}=$ original population $\mathrm{C}_{1}=$ first cycle population $\mathrm{C}_{2}=$ second cycle population (synthetic) 
Table 4: T-test table of comparison between the first and second cycle populations of high amyl pectin

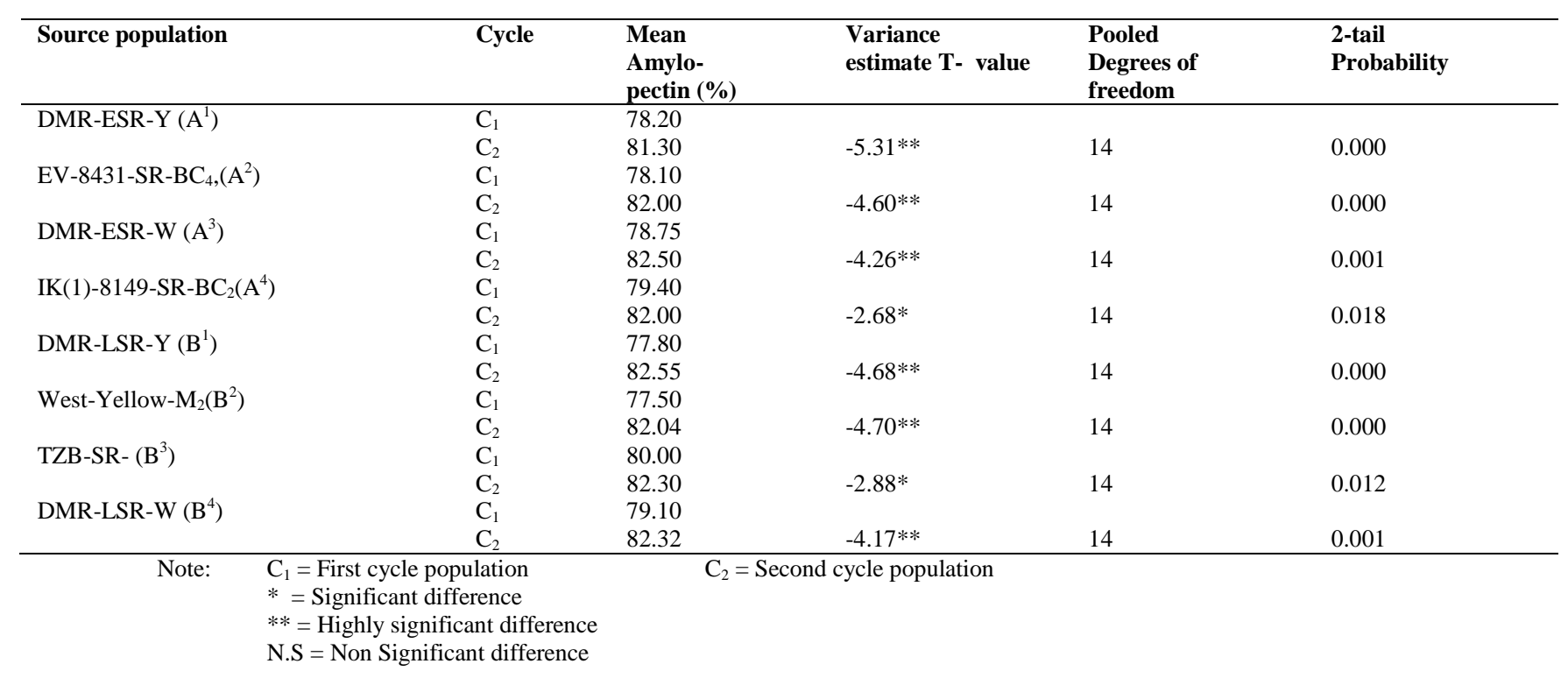

Table 5: Classification of oil, amylose and amylopectin contents of maize seeds

\begin{tabular}{llll}
\hline & \multicolumn{2}{c}{ Percentage content } \\
\hline Class & Oil & Amylose & Amylopectin \\
Low & $<4$ & $>20$ & $<70$ \\
Medium & $4-6$ & $20-30$ & $70-80$ \\
High & $>6$ & $>30$ & $>80$ \\
\hline Source: Obi and Ihedigbo $(1987)$ & & &
\end{tabular}

\section{REFERENCES}

Anon (2011). Waxy corn - Wikipedia, the free encyclopedia http//en.wikipedia.org/wiki/waxycorn: $1-10$

Baker, R. (1973). Black-layer development. World Farming 15, 14 -19.

Bear, R. P. (1958). The Story of amylomaize hybrids. Chemurgic Digest 17, 5.

Betty A. Lewis (2011). Starch: Encyclopedia of Food and culture. Enotes.com/foodencyclopedia/starch: $1-3$

Cameron J. W. (1947) Chemo-genetic bases for he reserve carbohydrates in maize endosperm. Genetics 32, 459-485.

Carmer, S. G. and Swanson, M. R. (1971). Detection of differences between means: A Monte Carlo study of five pairwise multiple comparison procedures. Agron. J. 63, 940-945

Comstock, R. E., Robinson, H. F. and Harvey, P.H (1949). A breeding procedure designed to make maximum use of both general and specific combining ability. Agron. J. 41, 360-367.

Creech, R. G. and Alexander, D. E (1978). Breeding for industrial and nutritional quality in maize. In:
Maize Breeding and Genetics. Edited by Walden, D. B John Wiley and Sons N. V. xv + 794pp.

Deatherage, W. L., McMasters, M. M., Vineyard, M.L. and Bear, R. P. (1954). A note on starch of high amylose content from corn with high starch content. Cereal Chem. $31,50-52$.

Douglas, A. G, Collier M. F., F. EL. Ebrashu, and Rogers, J. S. (1961) An Evaluation of three cycles of reciprocal recurrent selection on corn improvement programme. Crop science journal I: 157-161.

Fajemisin, J. M. (1985). Status of maize production technology in Nigeria and prospects for sustained selfsufficiency. Paper presented at NAFPP, $3^{\text {rd }}$ Joint Workshop, Owerri, Imo State, Nigeria, March 7-9

Hassid, W. Z., and McGready, R. W (1943). Separation and quantitative estimation of amylose and amylopectin in potato starch. J. Am. Chem. Soc. 65, 1154 
Jugenehimer, R. W. (1976). Corn: Improvement, seed production and uses. John Wiley and Sons, New York, 70pp.

Kramer, H. H. and Whistler, R. L. (1949). Quantitative effects of certain genes on the amylose content of corn endosperm starch. Agron. J. 41, 409 $-411$.

Neuffer, M. G. and Coe, E. H. (1997). Mutants of maize New York, Cold Spring Harbor Laboratory Press.

Obi, I. U and Onyishi, G. C. (1994). Development of High Protein population of maize ( $\underline{\text { Zea }} \underline{\text { Mays }} \mathrm{L}$ ) from two cycles of Reciprocal Recurrent selection. Samaru J. Agric Res. 11:63-68.

Obi, I. U. and Ihedigbo, N. E. (1987). Amylose, amylopectin, and oil content of some Nigeria maize cultivars. Niger. Agric. J. 22, 91 -100

Obi, I. U. (2002). Statistical Methods of Detecting Differences between Treatment Means and Research Method Issues in Laboratory and Field Experiments. Second Edition. Ap Express Publishers Ltd. 3 Obollo Road, Nsukka, Nigeria. pp. xiii + 117.
Onyishi, G. C. and Obi, I. U. (1991) Reciprocal Recurrent selection for increased protein, oil, Amylose and Amylopectin contents of two populations of maize (Zea Mays L) Nig. Agric Journal 25:58 - 68.

Smith, L. H. (1974). Ten generations of corn breeding. Crop Soc. Of Am., 65-92.

Steel, C. D and Torrier, J. H (1980). Principles and procedures of statistics. A Biometrical Approach. $2^{\text {nd }}$ edition. McGraw-Hill Book Co. Inc. New York, 481pp.

Vineyard, W. L and Bear, R. P. (1952). Amylose content. Maize Genetics Coop. Newsletter 26,5.

Wessler, S. R. and Varagona, M. J. (1985). Molecular basis of mutations at the waxy locus of maize: correlation with the fine structure genetic map. Genet. 82:4177 - 4181.

Zuber, M. S., Deatherage, W. L., Grogan, C. O. and McMasters, M. M (1960). Chemical composition of kernel fraction of corn. Agron. J. 52, 572.

Zuber, M. S., Grogan, C. O. Deatherage, W. L., Hubber, J. E. Schulze, W. E. and Mc Master M. M (1958). Breeding high amylose corn. Agron. J. 50, 9-12. 